\title{
DESAIN PROGRAM UNGGULAN PADA SISTEM ELECTRONIC- GOVERNMENT PEMERINTAH KABUPATEN SELUMA
}

\author{
Arius Satoni Kurniawansyah ${ }^{1}$, Rizka Tri Alinse ${ }^{2}$ \\ Universitas Dehasen Bengkulu \\ ariussatoni@unived.ac.id, rizkatri07@gmail.com
}

\begin{abstract}
The presence of an Electronic Government is information and telecommunications technology for efficient and effective government administration, as well as providing transparent and satisfying public services. The integration of information systems today greatly influences public institutions such as regional and central government. The current regional government system has begun to be integrated in a technology that can be controlled from the central government. An example is the application of electronic-government (e-Gov) which began to be implemented in Indonesia and in several regions. The stages of the research method are Application for permission for research from the Research and Community Service Institute of Dehasen University Bengkulu, Research Permit from Seluma Regency DPMPPTSP, Government data collection both manual and computerized, Grouping of Government data namely Regional Superior Program Name per each OPD in Seluma Regency in 2019. A cross-sectoral development program to create superior and prosperous Seluma District people by improving infrastructure, facilities and infrastructure, including tourism and leading sectors and optimizing superior products. One solution and alternative that promises to create transparency in realizing good governance is with an electronic government management system (e-government). Management of institutions / agencies electronically for both private and government in addition to increasing transparency, can also improve the quality of work produced by the Regional Government.
\end{abstract}

Keywords - Electronic-Government, Design, Governance, Transparent, Featured Program

\begin{abstract}
Abstrak - Hadirnya sebuah Electronic Government adalah teknologi modern dewasa ini sebagai pelayanan secara elektronik bagi pemerintah dengan memberikan pelayanan yang terbaik untuk masyarakat. Terintegrasinya sistem informasi dewasa ini sangat mempengaruhi lembaga-lembaga publik seperti pemerintah daerah dan Pemerintah Pusat. Sebuah system pemerintah sekarang sudah terintegrasi dalam sebuah teknologi yang dapat monitor oleh pemerintahan pusat. Contohnya adalah sekarang penerapan electronic-government (e-Gov) telah di implementasikan di Indonesia dan di beberapa daerah. Tahapan metode penelitiannya adalah Permohonan izin untuk penelitian dari Lembaga LPPM Universitas Dehasen Bengkulu, Izin penelitian dari DPMPPTSP Kabupaten Seluma, Pengumpulan data Pemerintahan baik yang masih manual maupun yang sudah terkomputerisasi, Pengelompokan data Pemerintahan yakni Nama Program Unggulan Daerah per setiap OPD di Kabupaten Seluma Tahun 2019. Program pembangunan lintas sektoral guna mewujudkan masyarakat Kabupaten Seluma yang unggul dan sejahtera dengan meningkatkan infrastruktur, sarana dan prasarana, termasuk wisata serta sektor unggulan dan optimalisasi produk unggulan. Ada sebuah alternative yang dapat digunakan untuk membangun sebuah transparansi dalam mewujudkan Pemerintahan yang baik adalah dengan sebuah e-government. Pengelolaan Lembaga secara digital baik untuk swasta maupun Pemerintah selain dapat meningkatkan transparansi, juga dapat meningkatkan kualitas kerja yang dihasilkan oleh Pemerintah Daerah.
\end{abstract}

Kata Kunci - Electronic-Government, Desain, Pemerintahan, Transparan, Program Unggulan 


\section{PENDAHULUAN}

Perananan pemerintah dalam memberikan sebuah layanan terhadap masyarakat menjadi prioritas, hal ini menjadikan berbagai fasilitas layanan yang digunakan oleh pemerintah selalu mengedepankan kepuasan pelayanan, efektifitas pelayanan dan efisiensi dalam pengelolaannya. Hal inilah yang menjadikan pemerintah selalu berupaya memberikan yang terbaik kepada masyarakat yaitu dengan cara meningkatkan pelayanan, solusinya adalah dengan cara membuat suatu sistem informasi yang terintegrasi antar lembaga pemerintahan untuk meningkatkan pelayanan. Salah satu bentuk pelayanan yang diberikan pemerintah adalah membangun sebuah konsep e-Government pada setiap tingkatan instansi pemerintah. [1]

Dalam Penelitian Eko Eddya Supriyanto tahun 2016 mengenai e-government yang dapat meningkatkan kualitas pelayanan public di Indonesia, menghasilkan sebuah inovasi pembangunan egovernment dengan penggabungan dari strategi pembangunan dan pengembangan pelayanan public berbasis teknologi digital yang ada di lapangan dengan teknotogi berbasis Short Message Service (SMS) yang tentunya lebih memanjakan pelanggan-pelanggan pemerintah yakni masyarakat. Sistem e-government dibangun dengan membuat kerangka arsitektur yang terdiri dari 4 lapis struktur yaitu: Akses, portal pelayanan public, organisasi pengelolaan dan pengolahan informasi dan infrastruktur serta aplikasi dasar. [2]

Pada Penelitian Titon Slamet Kurnia., dkk dengan judul e-government dalam penyelenggaraan Pemda di Indonesia menjelaskan mengenai landasan teoritis untuk pengimplementasian e-government dalam penyelenggaraan pemerintah daerah adalah konsepsi hukum administrasi baru (new administration law) yang lebih menekankan pada isu-isu kontemporer seperti perlunya akuntabilitas dan efisiensi pemerintahan. Konsepsi hukum administrasi baru ini secara simbolis biasa disebut dengan istilah good government atau good administration. [3]

Sementara pada penelitian ini, saya akan mendesai sebuah system e-government berbasis website pada pemerintah daerah Kabupaten Seluma Provinsi Bengkulu dengan menekankan pada informasi mengenai Program Unggulan Pemerintah Kabupaten Seluma. Informasi public tersebut harus dapat dengan mudah diakses oleh seluruh masyarakat Kabupaten Seluma khususnya melalui portal web resmi dalam mengawal dan mengkoreksi serta menilai kinerja pemerintah Kabupaten Seluma.

Dengan demikian maka akan tercipta sebuah Sistem Pemerintahan yang baik, bersih dan transparan dengan mengedepankan Kinerja dan Transparansi kepada publik.

\section{METODE PENELITIAN}

Dalam metodologi penelitian ini, ada urutan langkah kerja yang harus dikerjakan, kerangka kerja ini merupakan gambaran dari langkah-langkah yang harus dilalui agar penelitian ini terlaksana dengan sukses. Kerangka kerja yang harus dikerjakan sesuai dengan Metode SDLC (Sistem Development Life Cycle) dan bisa dilihat pada gambar 1 .

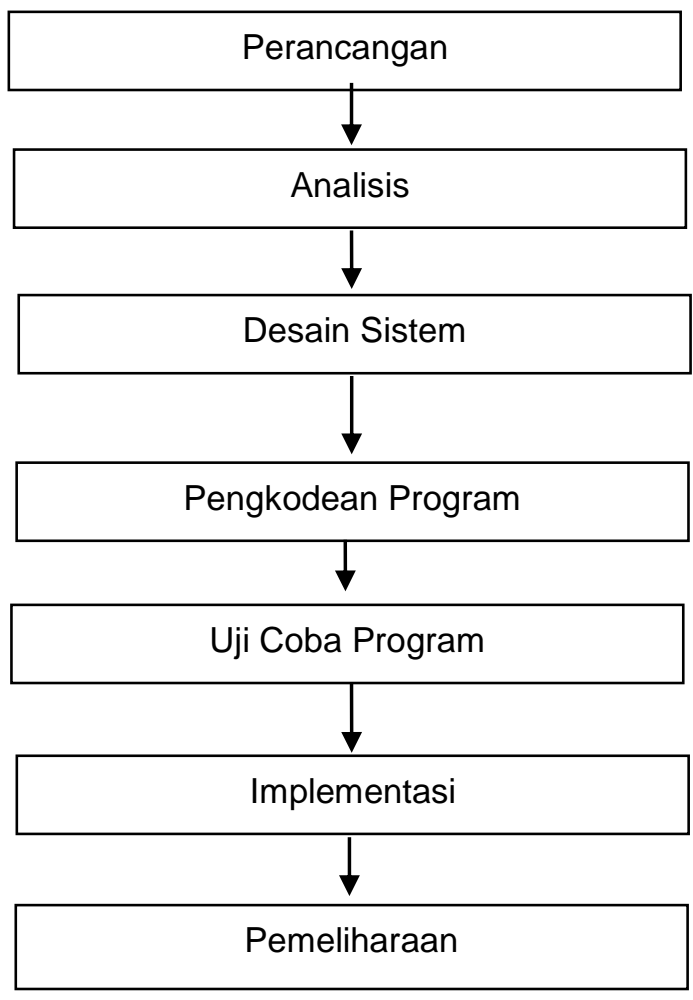

Gambar 1. Kerangka Kerja

Adapun Gambar Rancangan Sistem ElectronicGovernment yang akan dibangun untuk Pemerintah Kabupaten Seluma adalah seperti gambar berikut ini :

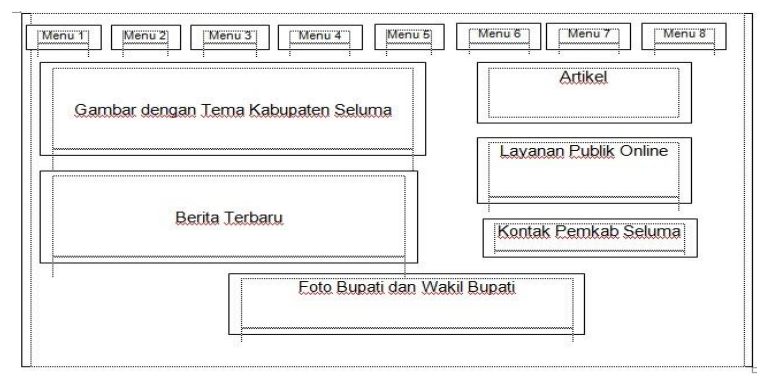

Gambar 2. Rancangan Desain Sistem E-Government Pemkab Seluma 
Adapun Keterangan dari gambar Rancangan Sistem E-Government Pemkab Seluma Provinsi Bengkulu adalah sebagai berikut :

Menu 1 : Beranda

Menu 2 : Profil Daerah

Menu 3 : Berita

Menu 4 : Publikasi

Menu 5 : Galeri

Menu 6 : Kontak

Menu 7 : Sakip

Menu 8 : Roadmap RB

\section{HASIL DAN PEMBAHASAN}

\section{A. Pemerintahan Kabupaten Seluma}

Kabupaten Seluma terletak di pantai Barat Sumatera bagian Selatan dengan koordinat garis lintang dan bujur yaitu 03.49'55'66" LS 04.21"40'22" LS dan 101.17'27'67" BT - 102 59'40'54" BT dan luas wilayah $240.004 \mathrm{Ha}$, Seluma merupakan Kabupaten dengan luas wilayah terbesar nomor ketiga di Propinsi Bengkulu. Wilayah Kabupaten Seluma berbatasan langsung dengan Kota Bengkulu, Kabupaten Bengkulu Utara, Kabupaten Bengkulu Selatan, Kabupaten Lahat Propinsi Sumatera Selatan dan Samudra Hindia.

Tata kepemerintahan yang baik atau good governance berhubungan sangat erat dengan hak-hak asasi. Dalam hukum administrasi, negara-negara anggota Uni Eropa sudah menyelenggarakan berbagai kegiatan ilmiah dengan membahas prinsip-prinsip Good Governance yang dikaitkan dengan hukum administrasi Eropa. [4]

Adapun Program Pemkab Seluma tahun 2019 adalah Program pembangunan lintas sektoral guna mewujudkan masyarakat Kabupaten Seluma yang unggul dan sejahtera dengan meningkatkan infrastruktur, sarana dan prasarana, termasuk wisata serta sektor unggulan dan optimalisasi produk unggulan. [5]

Untuk membangun Sebuah Sistem E-Government, diawali dengan Membuat Rancangan Desain Sistem dengan cara memetakan menu-menu apa yang akan ditampilkan pada Website Resmi Pemkab Seluma. Langkah selanjutnya adalah menganalisis Sistem, apakah Sistem yang sudah dirancang sesuai dengan kebutuhan dan untuk mengidentifikasi permasalahanpermasalahan yang terjadi serta kebutuhan-kebutuhan yang diharapkan sehingga dapat diusulkan untuk perbaikan-perbaikannya. Analisis Sistem juga dapat dilakukan dengan Observasi secara langsung, dengan Wawancara terhadap pihak yang terkait dan Studi Pustaka terhadap Literatur-literatur yang Relevan mengenai Electronic-Government. Dalam mendesain Sistem E-Government ini lebih menitik beratkan di bidang Informasi Publik mengenai Program Unggulan Pemkab Seluma.

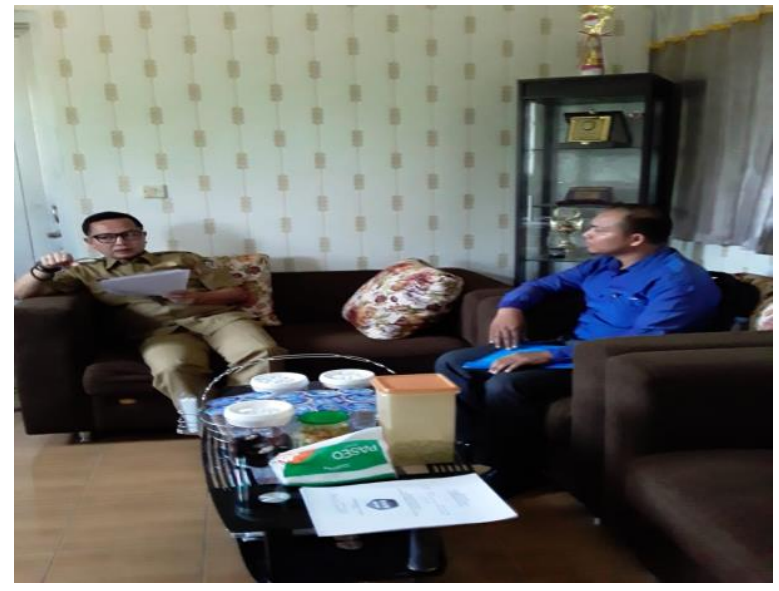

Gambar 3. Kegiatan Wawancara dengan Kadishub Kominfo Pemkab Seluma

Selanjutnya adalah tahapan kegiatan mendesain Sistem dan Pengkodean Program serta Uji coba Program. Adapun mendesain Sistem E-Government berbasis Website pada Pemkab Seluma dengan menggunakan Pemrograman Macromedia Dreamweaver 8.0. Adapun tampilan utama Program Aplikasi Macromedia Dreamweaver 8.0 seperti pada gambar berikut ini:

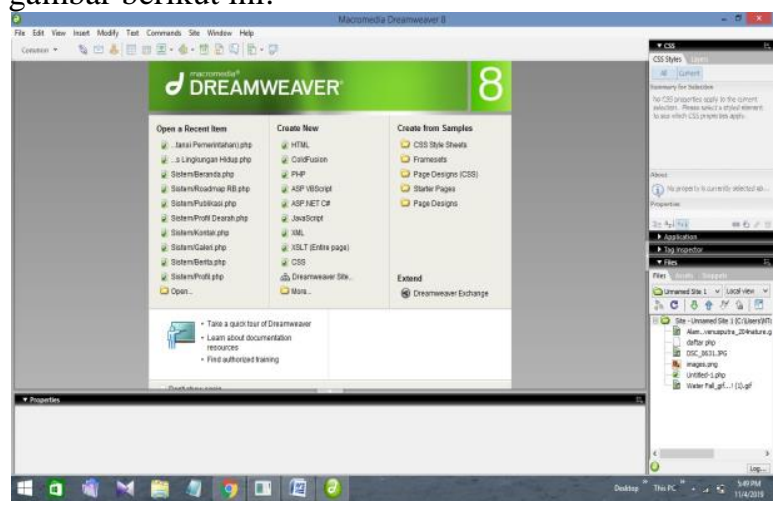

Gambar 4. Tampilan Utama Aplikasi Macromedia Dreamweaver 8.0

Pada Proses Pengkodean Program untuk diimplementasikan dalam pembangunan Sistem EGovernment yakni dengan bekerja pada Dashboard Macromedia Dreamweaver 8.0, dengan mensetting dan mendesain sesuai Rancangan Sistem EGovernment yang ingin dibuat.

Berikut hasil Desain menu Utama atau Beranda pada Sistem E-Government Pemerintah Kabupaten Seluma Provinsi Bengkulu. 


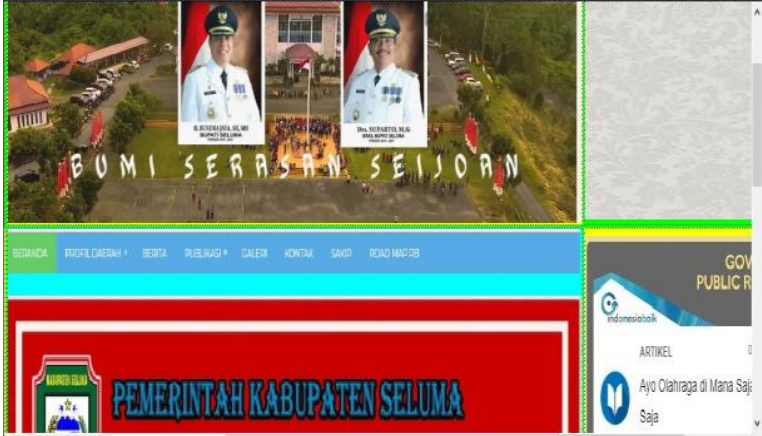

Gambar 5. Tampilan Beranda pada Sistem EGovernment Pemkab Seluma

Selanjutnya Gambar tampilan Menu Sistem Akuntabilitas Kinerja Instansi Pemerintahan (SAKIP) sebagai Informasi Publik mengenai Program Unggulan Pemerintah dan Capaian Kinerja setiap OPD di Lingkungan Pemkab Seluma.
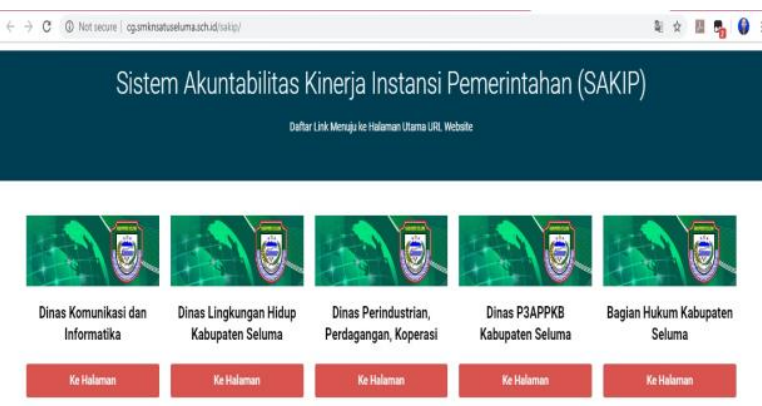

Gambar 6. Tampilan Menu SAKIP pada Sistem EGovernment Pemkab Seluma

Adapun salah satu tampilan isi dari Setiap Sub Menu pada Menu SAKIP adalah seperti tampilan gambar berikut ini:

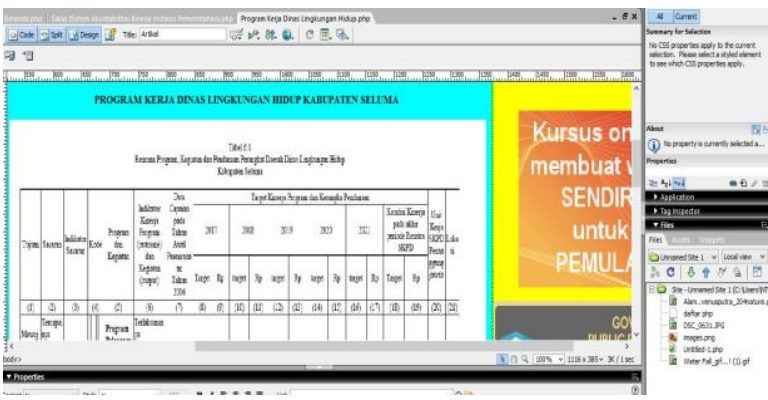

Gambar 7. Tampilan Program Kerja atau Program Unggulan di Dinas Lingkungan Hidup pada Sistem EGovernment Pemkab Seluma

Prinsip-prinsip pada pelayanan publik diimplementasikan sebagai usaha peningkatan kualitas di dalam penyediaan pelayanan pada public, termasuk dalam hal sebagai dasar pengembangan electronicgovernment, prinsip tersebut yakni aksesibilitas, kontinuitas, teknikalitas, profitabilitas, dan akuntabilitas. [6]

\section{KESIMPULAN DAN SARAN}

\section{A. Kesimpulan}

Solusi dan alternatif yang menjanjikan dalam menciptakan transparansi dan mewujudkan Pemerintahan yang baik adalah sebuah sistem pengelolaan pemerintahan berbasis digital atau electronic government.

\section{B. Saran}

Diharapkan kepada peneliti selanjutnya untuk dapat mengembangkan hasil penelitian ini menjadi lebih baik lagi di masa-masa yang akan datang.

Ucapan Terima Kasih

Terima kasih kami ucapkan kepada Kemenristek Dikti atas bantuan dan dukungannya terhadap penelitian saya.

Daftar Pustaka

[1] Somantri, oman $\mathrm{dkk}$, Implementasi $e$ Government Pada Kelurahan Pesurungan Lor Kota Tegal Berbasis Service Oriented Architecture (SOA), Jurnal Jurnal Informatika:Jurnal Pengembangan IT (JPIT) , Vol. 2, No. 1, Januari 2017 ISSN: 2477-5126, eISSN: 2548-9356

[2] Supriyanto, Eko Eddya. Kebijakan Inovasi Teknologi Informasi (IT) Melalui Program Elektronik Goverment dalam Meningkatkan Kualitas Pelayanan Publik di Indonesia. Jurnal Ilmu Pemerintahan : Kajian Ilmu Pemerintahan dan Politik Daerah. Vol. 1 No. 1 April 2016. Hal. 141-161. ISSN 2503-4685

[3] Kurnia, Tito Slamet., dkk. E-Government dalam Penyelenggaraan Pemerintah Daerah di Indonesia. Jurnal Masalah-masalah Hukum. Jilid 46 No. 2 April 2017. 170-181. ISSN 2086-2695

[4] Suprianto, Edy. 2014. "Pengaruh Penerapan Tata Kelola Pemerintahan Yang Baik Dan Teknologi Informasi Terhadap Kinerja Satuan Kerja Perangkat Daerah (Skpd) Guna Mendukung Implementasi Otonomi Daerah". Semarang, Universitas Sultan Agung Semarang

[5] Musrenbang, Pemkab Seluma Akan Terima Bantuan Anggaran. Diakses tanggal 21 Juni 2019.

https://www.tuntasonline.com/2019/03/20/musre 
nbang-pemkab-seluma-akan-terima-bantuan-

anggaran

[6] Pratama, Rizky Hersya., Hakim, Abdul dan Shobaruddin. Muhammad. 2012. Pelayanan Publik Berbasis Teknologi Informasi Dan Komunikasi (Tik), Elektronik Rukun Tetangga/Rukun Warga (E-Rt/Rw) Di Kelurahan Ketintang Kecamatan Gayungan Pemerintah Kota Surabaya. Jurnal Administrasi Publik (JAP). 3(12): 2128-2134 